\title{
Article \\ Equity Carve-Outs, Dual Directors, and Internal Labor Markets
}

\author{
Pengda Fan
}

Citation: Fan, Pengda. 2022. Equity Carve-Outs, Dual Directors, and Internal Labor Markets. International Journal of Financial Studies 10: 16. https://doi.org/10.3390/ ijfs10010016

Academic Editor: Sabri Boubaker

Received: 3 January 2022

Accepted: 18 February 2022

Published: 23 February 2022

Publisher's Note: MDPI stays neutral with regard to jurisdictional claims in published maps and institutional affiliations.

Copyright: (C) 2022 by the author. Licensee MDPI, Basel, Switzerland. This article is an open access article distributed under the terms and conditions of the Creative Commons Attribution (CC BY) license (https:// creativecommons.org/licenses/by/ $4.0 /)$.
College of International Management, Ritsumeikan Asia Pacific University, 1-1 Jumonjibaru Beppu, Oita 874-8577, Japan; p-fan@apu.ac.jp

\begin{abstract}
Given the prevalence of dual directors who serve simultaneously on the parent as well as the subsidiary board, it is important to examine their functions, a topic largely ignored in the existing literature. Exploring the functions of dual directors highlights equity carve-out objectives other than strategic refocusing. To examine our hypothesis, we first conducted an event study to examine stock market reaction to carve-out decisions. In addition, we compared subsidiaries' performance after carve-outs between firms with dual directors and their matching firms based on the propensity score. We find evidence that the Japanese stock market reacts positively to the presence of dual directors who hold CEO positions in carve-out subsidiaries, especially when they are relatively young. Additionally, we find that carve-out subsidiaries led by young dual directors tend to outperform their matched counterparts in the long run. In contrast, when dual directors do not hold the CEO position, we find no evidence of the stock market reacting positively to them. The results of this study suggest that young CEOs appointed from the internal labor markets care more about long-term reputation, and can enhance shareholder wealth of both parent and subsidiary firms.
\end{abstract}

Keywords: equity carve-out; dual directors; internal labor markets

\section{Introduction}

This study investigates the role of dual directors-people who serve simultaneously on the board of the parent firm as well as the carve-out firm-in enhancing shareholder wealth. In an equity carve-out, parent firms sell a part of their subsidiaries' shares through an initial public offering (IPO) and continue to hold controlling interests in the carve-out subsidiaries. Conventional wisdom is that poorly performing or financially constrained firms have an incentive to conduct asset divestitures (carve-outs or spin-offs) with the aim to refocus on their core businesses. ${ }^{1}$ This fact suggests that parent companies, post carve-outs, will ultimately exit from the subsidiaries though secondary events (Klein et al. 1991; Otsubo 2009). ${ }^{2}$

However, there is a burgeoning literature that suggests that some firms tend to retain a majority of the ownership of their subsidiaries in the long term or re-acquire the subsidiaries during the post-carve-out period (Desai et al. 2011; Otsubo 2013; Perotti and Rossetto 2007), which implies that firms may conduct carve-outs for different motivations. A significant number of board directors of carve-out firms are appointed by parent firms (Allen and McConnell 1998; Aron 1991; Desai et al. 2011; Feldman 2016; Schipper and Smith 1986; Seward and Walsh 1996), allowing the parent firms to exert substantial controlling power over subsidiaries. Given the prevalence of dual directors, it is important to examine their functions, a topic largely ignored in the existing literature. Exploring the functions of dual directors also highlights equity carve-out objectives other than strategic refocusing.

While the role of corporate boards is conventionally viewed as one of providing monitoring and advising functions, Hermalin and Weisbach (1988) suggest that an insiderdominated board acts an internal labor market for the education of the next CEO. However, as employees move up the corporate ladder, positions at the top become scarce, which means that many competent employees cannot move up after a point due to the limited 
positions available. An equity carve-out can mitigate this issue by providing capable employees top management positions as well as market-based incentives (Aron 1991; Ito 1995; Ito and Rose 1994). Consequently, we hypothesize that the internal labor market discipline can motivate dual directors to improve the long-term performance of subsidiaries and enhance the shareholder wealth of parent firms if the parent firms continue to hold the majority ownership of the subsidiaries.

Delving into the issue, we examine the heterogeneity of dual directors by taking into consideration their age and the positions they hold in the subsidiaries. We expect that the CEO position in subsidiaries provides a big tournament incentive to those in the internal labor markets. Regarding the effects of CEO age on firm performance, the extant literature on career concerns provides two competing views. The short-term reputation-building hypothesis argues that younger CEOs have an incentive to build reputation through pursuing short-term profits when the information asymmetry is high. Contrastingly, the long-term career concern hypothesis states that CEOs with longer contract duration would prefer long-term profits. Considering that CEO dual directors are appointed by the parent firms that continue to be the largest shareholder even after the equity carve-outs, information asymmetry should be less of a concern, suggesting that younger CEO are less likely to act opportunistically. Consequently, we expect younger CEOs appointed by parent firms to care more about long-term reputation.

We use the Japanese equity carve-outs made between 2001 and 2016 to explore our hypothesis. Japanese boards are expected to serve as an internal labor market consisting of candidates for the next top manager position under the lifelong employment system (Basu et al. 2007; Coles and Uchida 2018; Ito 1995). Japanese groups with a large number of listed subsidiaries, and with parent-subsidiary relationships that have continued for decades, are common (Otsubo 2009).

As Panel A of Table 1 shows, approximately 54\% of the sample firms have at least one dual director and, as shown in Panel B of Table 2, 24\% of the CEOs of carve-out firms simultaneously serve on the parent boards. We also find that more than $80 \%$ of parent firms conducting equity carve-outs remained as the largest shareholders of the divested subsidiaries five years after the carve-outs, suggesting that many Japanese companies have different objectives for carve-outs, not just divestiture.

Table 1. Descriptive statistics for equity carve-outs. Panel A reports the annual frequency of equity carve-outs during the period 2001 through 2016. Panel B reports the industry distribution. Panel C reports the percentage of ownership of the subsidiary by the parent company.

Panel A: Yearly Distribution of Equity Carve-Outs

\begin{tabular}{cccc}
\hline Year & $\begin{array}{c}\text { Number of Carve-Outs } \\
{[1]=[2]+[3]}\end{array}$ & $\begin{array}{c}\text { Number of firms with at least } \\
\text { one dual director [2] }\end{array}$ & $\begin{array}{c}\text { Number of firms without a } \\
\text { dual director [3] }\end{array}$ \\
\hline 2001 & 18 & 9 & 9 \\
2002 & 10 & 3 & 7 \\
2003 & 12 & 9 & 3 \\
2004 & 25 & 12 & 13 \\
2005 & 12 & 9 & 3 \\
2006 & 14 & 9 & 5 \\
2007 & 15 & 7 & 8 \\
2008 & 4 & 3 & 1 \\
2010 & 2 & 1 & 1 \\
2011 & 2 & 1 & 1 \\
2012 & 1 & 0 & 1 \\
2013 & 2 & 0 & 2 \\
2014 & 4 & 2 & 2 \\
2015 & 4 & 2 & 2 \\
Total & 5 & 3 & 60 \\
\hline
\end{tabular}


Table 1. Cont.

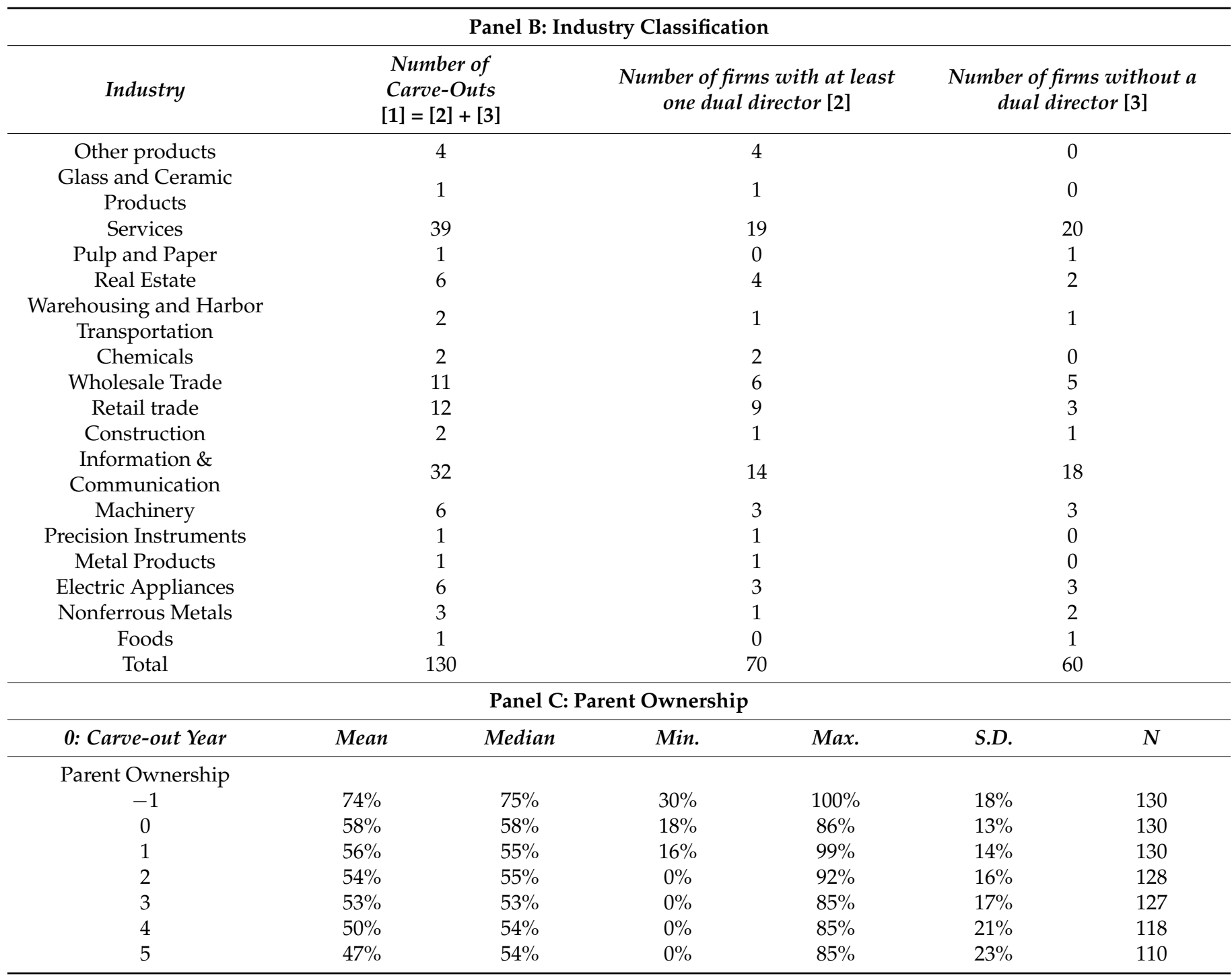

Our empirical analyses find that parent firms' recorded an average cumulative abnormal return (CAR) of $2.8 \%$ over the five-day interval surrounding carve-out announcements, indicating that as in the U.S., equity carve-outs in Japan enhance the wealth of the parent firms' shareholders. When the sample is divided into subsamples in accordance with the positions dual directors hold in the carve-out firms, the difference in CAR is substantial and statistically significant. When dual directors hold the CEO position in subsidiaries, the average CAR is $5.9 \%$, which is significantly different from all the other firms $(1.8 \%)$. When dual directors younger than 60 hold the CEO position in carve-out firms, the average CAR increases to $6.3 \%$. In contrast, when dual directors do not hold the CEO position, we find no evidence that the stock market reacts positively to them. These results indicate that the stock market expects the dual directors awarded with the CEO position to increase the value of their (carve-out) firms, and ultimately the value of their parent firms. Complementing the previous results, we also find that in companies where dual directors hold the CEO position, especially the relatively younger ones, there is a significant improvement in the performance of the firms ( $R O A$ and Tobin's $Q$ ). This improvement is more than that of their control firms, which is matched by the propensity score during the post-carve-out period. In addition, we perform a battery of tests to control for alternative stories and a different definition of variables. Overall, our results suggest that dual directors create value 
for both the carve-out and parent companies, and that the CEO position provides younger employees in the internal labor markets with a strong incentive to work hard.

Table 2. Descriptive statistics for dual directors. Panel A reports the frequency of dual directors on both parent and subsidiary boards. Panel B reports the distribution of different types of dual directors based on whether they hold the CEO position in the subsidiary firm and whether they are younger than 60 years old. CEO position (non-CEO position) are subsidiary firms with dual directors who hold the CEO (non-CEO) position in the subsidiary firms. ${ }^{3}$ CEO position $\mathcal{E}$ Young (Non-CEO position $\mathcal{E}$ Young) are subsidiary firms with dual directors who hold the CEO (non-CEO) position in the subsidiary firms and are younger than 60 years old.

\begin{tabular}{|c|c|c|c|c|c|}
\hline \multicolumn{6}{|c|}{ Panel A: Distribution of dual directors } \\
\hline \multicolumn{2}{|c|}{ Number of Dual Directors } & \multicolumn{2}{|r|}{ Freq. } & \multicolumn{2}{|c|}{ Percent } \\
\hline \multicolumn{2}{|l|}{0} & \multicolumn{2}{|r|}{60} & \multicolumn{2}{|c|}{$46 \%$} \\
\hline \multicolumn{2}{|l|}{1} & \multicolumn{2}{|r|}{46} & \multicolumn{2}{|c|}{$35 \%$} \\
\hline \multicolumn{2}{|l|}{2} & \multicolumn{2}{|r|}{15} & \multicolumn{2}{|c|}{$12 \%$} \\
\hline \multicolumn{2}{|l|}{3} & \multicolumn{2}{|r|}{6} & \multicolumn{2}{|c|}{$5 \%$} \\
\hline \multicolumn{2}{|l|}{4} & \multicolumn{2}{|r|}{1} & \multicolumn{2}{|c|}{$1 \%$} \\
\hline \multicolumn{2}{|l|}{5} & \multicolumn{2}{|r|}{1} & \multicolumn{2}{|c|}{$1 \%$} \\
\hline \multicolumn{2}{|l|}{7} & \multicolumn{2}{|r|}{1} & \multicolumn{2}{|c|}{$1 \%$} \\
\hline \multicolumn{2}{|l|}{ Total } & \multicolumn{2}{|r|}{130} & \multicolumn{2}{|c|}{$100 \%$} \\
\hline \multicolumn{6}{|c|}{ Panel B: The heterogeneity of dual directors } \\
\hline CEO Position & Freq. & Percent & CEO Position $\mathcal{E}$ Young & Freq. & Percent \\
\hline 0 & 100 & $77 \%$ & 0 & 110 & $85 \%$ \\
\hline 1 & 28 & $22 \%$ & 1 & 20 & $15 \%$ \\
\hline 2 & 2 & $2 \%$ & Total & 130 & $100 \%$ \\
\hline Total & 130 & $100 \%$ & & & \\
\hline Non-CEO position & Freq. & Percent & Non-CEO position E Young & Freq. & Percent \\
\hline 0 & 78 & $60 \%$ & 0 & 91 & $70 \%$ \\
\hline 1 & 36 & $27.69 \%$ & 1 & 31 & $24 \%$ \\
\hline 2 & 11 & $8.46 \%$ & 2 & 5 & $4 \%$ \\
\hline 3 & 2 & $1.54 \%$ & 3 & 1 & $1 \%$ \\
\hline 4 & 2 & $1.54 \%$ & 4 & 1 & $1 \%$ \\
\hline 6 & 1 & $0.77 \%$ & 5 & 1 & $1 \%$ \\
\hline Total & 130 & $100 \%$ & Total & 130 & $100 \%$ \\
\hline
\end{tabular}

Our research makes several important contributions to the literature. First, numerous studies have attempted to explore why equity carve-outs and spin-offs create value for the parent firms from the perspectives of refocusing (Allen and McConnell 1998; Daley et al. 1997; Otsubo 2009; Schipper and Smith 1986). We extend this strand of literature by highlighting the heterogeneous motives of carve-outs. Second, while prior studies on strategy research have paid attention to the fact that some companies, both in Japan and the U.S., they tend to conduct multiple equity carve-outs and preserve the parentsubsidiary relationship for a long time (Allen 1998; Feldman 2016; Ito 1995; Ito and Rose 1994), the interaction between parent firms and subsidiaries has not yet been well examined. We argue that, by creating new public firms, parent firms can provide promising young employees with more top management positions and market-based incentives, which will induce them to work harder toward enhancing shareholder wealth. Third, while the existing literature provides mixed results on how career concerns affect financial decisions of independent firms (Li et al. 2017; Yim 2013), our results suggest that younger CEOs appointed from the internal labor markets care more about long-term reputation. Lastly, in the past decades, many countries have followed the U.S. good governance practice of 
majority-independent boards for the mandated firms. However, studies also show that the one-size-fits-all approach does not work well even within the U.S. (Coles et al. 2008). Our research provides additional evidence for the role of Japanese boards as the internal labor market in the context of equity carve-outs.

The remaining paper is organized as follows. Section 2 presents the literature review, hypothesis development, and institutional background. Section 3 describes sample selection and data. Section 4 presents the primary empirical results of our research, and Section 5 concludes.

\section{Literature Review, Hypothesis Development and Institutional Background}

\subsection{How Do Equity Carve-Outs Enhance Shareholder Wealth?}

The literature offers several reasons for equity carve-outs and spin-offs. The first reason is divestiture. By conducting equity carve-outs or spin-offs, parent companies can refocus on their core business, and thus improve their performances (Ahn and Walker 2007; Allen and McConnell 1998; Berger and Ofek 1995; Burch and Nanda 2003; Dasilas and Leventis 2018; Fuchs 2003; Hulburt et al. 2002; Otsubo 2009; Slovin et al. 1995). Consistent with this idea, they find that in the case of firms that are performing poorly, highly diversified, and leveraged as more likely to conduct divestitures, the stock market usually shows a positive abnormal return in response to the announcement of their divestiture.

Another strand of literature is premised on information asymmetry. Nanda (1991), Powers (2003) and Slovin et al. (1995) argue that parent firms tend to conduct equity divestitures when they are undervalued, and choose to sell overvalued subsidiaries. Focusing on the bright side, Bergh et al. (2008) and Perotti and Rossetto (2007) demonstrate that carve-outs present a real option to parent companies to attract information from the market regarding the intrinsic value of their subsidiaries as well as the synergy with the subsidiaries, which facilitates the decision about whether they should completely exit or regain control of the subsidiaries. Some parent firms have decided to end the parent-subsidiary relationship through secondary events (Klein et al. 1991; Otsubo 2009), and some ultimately re-acquire the subsidiaries (Desai et al. 2011).

The third reason is the incentive hypothesis. Prior studies suggest that carve-outs can enhance shareholder wealth because they can revise the incentive contracts of subsidiary managers, thereby realigning the interests of managers with those of shareholders (Michaely and Shaw 1995; Schipper and Smith 1986). Our research extends this literature by investigating the functions of dual directors in carve-out firms.

\subsection{The Interaction between Parent Firms and Carve-Out Subsidiaries}

While an equity carve-out creates a new public firm, parent firms can continue to exert a substantial influence on their subsidiaries through various channels. First, most of the parent firms remain the largest shareholders even after the carve-out, which allows them to appoint a top management team for the subsidiaries (Allen and McConnell 1998; Desai et al. 2011; Wruck and Wruck 2002). ${ }^{4}$ In addition, parent firms can also create long-term business agreements with subsidiaries (Atanasov et al. 2010). Furthermore, if the subsidiaries are highly dependent on parent firms, parent firms may have the incentive to structure their interactions with the subsidiaries with weak bargaining power to their benefit, yet costly to the subsidiaries (Gulati and Sytch 2007). An important feature of carve-outs or spin-offs is the presence of dual directors (Boone et al. 2003; Chahine and Zeidan 2014; Feldman 2016; Schipper and Smith 1986). Accordingly, this study seeks to explore their functions.

\subsection{Hypothesis Development}

The literature built on agency cost theory suggests that managers who have empirebuilding tendencies are reluctant to conduct corporate divestitures. If CEOs of parent firms aim to retain the controlling power of the subsidiaries for private benefits, dual directors would be detrimental to the carve-out firms. This is especially true when there is a large discrepancy between cash flow rights and control rights. Indeed, Feldman (2016) found 
dual directors displaying a tendency to expropriate the wealth of minority shareholders in spinoff firms. In addition, busy boards have been documented to be less effective in terms of monitoring function (Chen and Guay 2020; Core et al. 1999). Using the sample of Forbes 500 firms, Fich and Shivdasani (2005) found that firms with busy outside directors are associated with lower profitability and firm value. Furthermore, overlapping boards may limit subsidiaries' managerial discretion and lead to potential conflicts of interests between them and their parent firms (Chahine and Zeidan 2014; Feldman 2016).

However, dual directors can also confer substantial benefits to carve-out firms. As argued by Field et al. (2013), while busy boards are detrimental in large and matured firms, new public firms have a stronger demand for advising roles. Thus, parent boards that are more experienced and likely to have strong industrial connections can offer valuable advice to firms with little experience in public markets. Indeed, Field et al. (2013) found a positive relationship between the number of busy boards and new public firms' values. Another strand of literature suggests that high-quality directors are more likely to serve on multiple boards (Brickley et al. 1999; Bugeja et al. 2009; Coles and Hoi 2003; Gilson 1989, 1990). Considering that parent firms continue to keep a majority of the divested subsidiaries shares after carve-outs, agency costs due to the discrepancy between cash flow rights and control rights, as illustrated in the case of spin-offs, should be less concerning. The above discussion gives rise to our first hypothesis:

Hypothesis 1. The benefits of dual boards likely outweigh the costs of new public subsidiaries.

We next explore the heterogeneity of dual directors by taking the positions they hold in subsidiaries into consideration. Dual directors can either take the CEO position or the non-executive position. While corporate boards conventionally provide monitoring and advising functions, Hermalin and Weisbach (1988) argued that an insider-dominated board acts an internal labor market for the next CEO. However, as top management roles are scarce, many competent employees cannot move up beyond a level, a problem an equity carve-out can mitigate by providing capable employees top management positions and market-based incentives (Aron 1991; Ito 1995; Ito and Rose 1994). Consistent with this idea, Seward and Walsh (1996) found that 48 of the 76 spin-offs are managed by inside CEOs. Therefore, we expect that dual directors who make CEOs are more motivated than those holding non-executive positions.

Hypothesis 2. Dual boards holding CEO positions are more valuable to subsidiary companies than those in non-executive positions.

Conditional upon the appointment of CEO dual directors, we further explore how career concerns affect the association between CEO dual directors and wealth effects. Extant literature provides two competing views on the effects of career concerns. One idea, which we call the short-term reputation-building hypothesis, argues that younger CEOs have an incentive to build reputation through pursuing short-term profits, especially when the information asymmetry is high (e.g., the investor is unaware of the abilities of younger CEOs), and they must signal their ability to the market. Consistent with this idea, Yim (2013) and Zhang et al. (2016) found that CEOs are prone to conduct M\&A earlier in their career at the expense of shareholder value. In a similar vein, managerial reputation building can also encourage myopia investment (Narayanan 1985) and overinvestment (Holmstrom and Costa 1986).

Another idea, called the long-term career concern hypothesis, states that CEOs with longer contract duration would prefer long-term profits. Building on the efficient contracting hypothesis, Fama (1980) showed that CEOs build up reputation over their career via repeated dealings with market participants. CEOs with poor performing records would experience an early dismissal or lower wages (Xie 2015). In addition, Li et al. (2017) found that younger CEOs are more likely to undertake bolder and riskier decisions (e.g., enter new lines of businesses; exit from existing ones) without hurting shareholder wealth. 
Considering that $\mathrm{CEO}$ dual directors are appointed by parent firms, which continue to be the largest shareholder even after the carve-out, information asymmetry should be less of a concern. Consequently, we expect younger CEOs appointed internally to act less opportunistically and care more about long-term reputation.

Hypothesis 3. Younger dual directors holding CEO positions are more beneficial for the subsidiary companies.

\subsection{Institutional Background}

We used Japanese equity carve-outs to explore our hypothesis. Japanese data are advantageous for two reasons: first, Japanese boards serve as an internal labor market consisting of candidates for the next top manager position under the lifelong employment system (Basu et al. 2007). To become CEOs, insiders need to serve in Japanese companies for many years as employees, and then take a board seat for a couple of years. Consistent with this idea, Coles and Uchida (2018) found that when a firm's board is dominated by junior insiders, the competition for the next CEO motivates them to contribute more to the firm, contributing to firm value. In contrast, outside directors cannot increase firm value in Japan (Miwa and Ramseyer 2005).

Second, Japanese groups with a large number of listed subsidiaries are common. As shown by Otsubo (2013), Hitachi group has 23 listed subsidiaries, and the parent-subsidiary relationships have been preserved by the group for over 20 years. Thus, we argue Japanese carve-out firms are less likely to be motivated by the refocus strategy that is popular in the U.S.

\section{Sample Selection and Data}

We collected the IPO prospectus of the carve-out subsidiaries that went public in the Japanese stock market from 2001 to 2016 through the eol service provided by Pronexus, which initially generated 253 carve-outs. We start our sample from 2001 because the eol service collects the electronic versions of the official reports of companies only since 2001 . We excluded carve-outs that had gone public after 2016 because we aimed to examine the longterm performances of the carve-out entities. The financial and stock price information of the parent and carve-out firms was obtained from Nikkei NEEDS Financial Quest, and the information on board directors was taken from the Toyokeizai Director database. The days on which the parent companies announced carve-out plans were searched and identified from the NIKKEI Telecom21 database. We excluded the following: (1) financial institutions and utilities firms; (2) firms whose financial, stock, or board director data for the year prior to the event are not available; (3) firms where the same parent firm has already conducted a carve-out in the past year, and (4) subsidiaries whose parent firms are not Japanese listed companies. Our final sample comprise 130 carve-outs.

To define the dual directors, we merged the information of parent boards with those of carve-out subsidiaries. We identified dual directors who serve simultaneously on the boards of parent and subsidiary firms. Panel A of Table 1 indicates 70 (54\% of 130) carve-out subsidiaries with at least one dual director. Panel B of Table 1 shows the industry distribution of carve-out subsidiaries. Firms in services, and information and communication industries account for $30 \%$ and $25 \%$, respectively. We found no difference in the industry distribution of firms with dual directors and those without. Regarding the parent-subsidiary relationship during the post-carve-out period, we found that the median parent ownership of five years after the equity carve-outs is $54 \%$, as in Otsubo (2013). This covered the Japanese equity carve-outs for 1985 to 2005, suggesting that a significant proportion of the firms are less likely to divest unwanted units. As Moschieri and Mair (2011) argued, while most of the existing studies assume that parent firms divest unwanted units, there is also an increased prevalence of the reacquisition of subsidiaries around the world, suggesting other motivations for conducting equity carve-outs than simply a well-documented divestiture. 
In this research, we classified dual directors into different types based on the positions they hold in their subsidiaries and their age. We defined the CEO Position (Non-CEO Position) as a dual director holding the position of a CEO (non-CEO) in a subsidiary. We further defined CEO Position \& Young (Non-CEO Position $\mathcal{E}$ Young) as a dual director who holds the CEO position (non-CEO) in a subsidiary and is below 60 years of age. ${ }^{5}$ Panel A of Table 2 presents the frequency of dual directors. We found 46 firms with one dual director and 24 firms with two or more dual directors. Panel B of Table 2 shows that the CEOs of 30 subsidiaries (approximately 23\%) serve simultaneously on parent boards, and 20 of them are below 60 years of age. Meanwhile, the dual directors of 52 subsidiaries are non-CEO directors.

To examine our hypothesis, we conducted an event study to examine the stock market reaction to carve-out decisions. We began by calculating the abnormal returns of parent firms around the announcement days. As Formula (1) shows, we used the five-factor model proposed by Fama and French (2015) to estimate the expected returns. Stock price data from day 273 to day 22 (day 0 indicates announcement day) were used to estimate the model parameters. Abnormal returns (AR) are the difference between the arithmetic returns and the expected returns. CAR is the cumulative abnormal returns for the $t$-day window (from day $-t$ to day $t$ ).

$$
R_{i t}-R_{F t}=a_{i}+b_{i}\left(R_{m t}-R_{F t}\right)+s_{i} S M B_{t}+h_{i} H M L O_{t}+r_{i} R M W_{t}+c_{i} C M A_{t}+e_{i t}
$$

We created seven dummy variables to capture the presence of dual directors. Dual director takes the value of 1 for firms with at least 1 dual director and 0 otherwise. Dual director holding CEO position takes the value of 1 for firms with at least 1 dual director holding the CEO position in one of their subsidiary firms and 0 otherwise. Young dual director holding CEO position takes the value of 1 for firms with at least 1 young dual director holding the CEO position in one of their subsidiary firms and 0 otherwise. Old dual director holding CEO position takes a value of 1 for firms with at least 1 dual director holding the CEO position (none of the CEO-dual directors are young) in the subsidiary firm, and 0 otherwise. Dual director holding Non-CEO position takes the value of 1 for firms with at least 1 dual director holding the Non-CEO position in one of their subsidiary firms and 0 otherwise. Young dual director holding Non-CEO position takes the value of 1 for firms with at least 1 young dual director holding a non-CEO position in one of their subsidiary firms and 0 otherwise. Old dual director holding non-CEO position takes a value of 1 for firms with at least 1 dual director holding non-CEO position (none of the non-CEO-dual directors are young) in the subsidiary firm, and 0 otherwise.

We also examined various control variables that potentially affect stock market reaction around the announcement day (see Appendix A Table A1 for the variable definition). Table 3 presents the summary statistics of parent firms (Panel A) and carve-out subsidiaries (Panel B). While the data for the year before the carve-outs are presented for financial variables, the IPO related variables (e.g., proceeds for parents and subsidiaries) are drawn from the IPO White Paper. Panel A of Table 3 indicates that the parent companies appointing dual directors to their subsidiaries are significantly smaller than those without dual directors (11.43 vs. 13.67). Leverage (total liabilities scaled by total assets) is $57 \%$ for the dual-director firms, which is significantly lower than that for the parent firms without dual directors. ROA (operating income divided by total assets) is $6.6 \%$ for the firms with dual directors and $4.5 \%$ for those without $(p<0.000)$, highlighting that a significant proportion of the equity carve-outs are not driven by parent firms' financial constraints, which has been largely ignored by previous studies. For Relative size (a subsidiary's total assets divided by the parent firm's total assets before carve-outs), we found that firms with dual directors tended to carve out larger subsidiaries than firms without ( $8 \%$ vs. $3 \%, p<0.000)$. Consistent with our internal labor market hypothesis, we find that the OUTSIDEBOARD (the number of outside board members divided by board size) is significantly lower for firms with dual directors. We found no significant difference in the proceeds raised by the 
parent firms and Same industry dummy (takes the value of 1 if a subsidiary and its parent company are in the same industry and 0 if otherwise).

Next, we compared the differences between the carve-out subsidiaries. While the subsidiaries with dual directors are smaller than their counterparts, we found no significant difference in the various firm characteristics: Leverage, ROA, CAPEXP (capital expenditures divided by total assets), asset tangibility (the ratio of tangible asset over total assets), OUTSIDEBOARD, Subsidiary proceeds (the primary proceeds raised by a subsidiary firm divided by the total assets of the subsidiary firm before carve-outs), CEO Age, Pyramid structure dummy (takes the value of 1 if a parent firm indirectly controls the carve-out firms and 0 otherwise). Meanwhile, we found that CEO ownership is $2.5 \%$ for firms with dual directors and $0.6 \%$ for firms without, indicating that the CEOs of the subsidiaries with dual directors' interest are more motivated to devote more efforts in improving the long-term performances of firms, which is also consistent with the premise of our hypothesis.

Table 3. Summary statistics of parent and carve-out subsidiary firms. Panel A compares characteristics of parent firms with dual directors and those without dual directors. Panel B compares characteristics of carve-out subsidiary firms with dual directors and those without dual directors. Ln (Total Assets) is the natural logarithm of total assets. Leverage is total liabilities scaled by total assets. ROA is operating income divided by total assets. Relative size is subsidiary's total assets divided by parent's total assets before carve-outs. Parent proceeds are secondary proceeds sold by parent firms divided by the parent's total assets before carve-outs. OUTSIDEBOARD is the number of outside board members divided by board size. The same industry dummy takes a value of 1 if a subsidiary and its parent are in the same industry and 0 otherwise. CAPEXP is capital expenditure divided by total assets. Tangible Asset is tangible assets over total assets. Subsidiary proceeds are the primary proceeds raised by a subsidiary firm divided by total assets of the subsidiary firm before carve-outs. Underpricing is the difference between initial price and offering price divided by offering price. CEO ownership is the percentage of shares owned by the CEOs. CEO age is the age of CEOs in the carve-out year. Parent ownership right after IPO is the percentage of shares owned by the parent firms right after the equity carve-out. Pyramid structure dummy takes a value of 1 if the parent firms indirectly control carve-out firms and 0 otherwise. Majority control dummy takes a value of 1 if parent ownership right after the IPO is more than $50 \%$ and 0 otherwise. Financial data preceding the equity carve-out are presented. All continuous variables are winsorized at the top and bottom five percent values. P-values are for mean (median) difference test. ${ }^{*}, * *$, and ${ }^{* * *}$ indicate significance at the $10 \%, 5 \%$, and $1 \%$ levels, respectively.

\begin{tabular}{ccccc}
\hline \multicolumn{5}{c}{ Panel A: Characteristics of parent firms } \\
\hline & Full sample & $\begin{array}{c}\text { Firm with dual } \\
\text { directors }\end{array}$ & $\begin{array}{c}\text { Firm without } \\
\text { dual directors }\end{array}$ & p-Value \\
\hline Ln (Total Assets) & $12.463[12.175]$ & $11.431[11.281]$ & $13.666[14.176]$ & $0.000^{* * *}$ \\
& $\mathrm{~N}=130$ & $\mathrm{~N}=70$ & $\mathrm{~N}=60$ & {$\left[0.000^{* * *}\right]$} \\
Leverage & $0.633[0.672]$ & $0.573[0.607]$ & $0.702[0.732]$ & $0.000^{* * *}$ \\
& $\mathrm{~N}=130$ & $\mathrm{~N}=70$ & $\mathrm{~N}=60$ & {$\left[0.001^{* * *}\right]$} \\
ROA & $0.056[0.045]$ & $0.066[0.056]$ & $0.045[0.034]$ & $0.011^{* * *}$ \\
& $\mathrm{~N}=130$ & $\mathrm{~N}=70$ & $\mathrm{~N}=60$ & {$\left[0.005^{* * *}\right]$} \\
Relative size & $0.059[0.036]$ & $0.080[0.067]$ & $0.034[0.013]$ & $0.000^{* * *}$ \\
& $\mathrm{~N}=130$ & $\mathrm{~N}=70$ & $\mathrm{~N}=60$ & {$\left[0.000^{* * *}\right]$} \\
Parent proceeds & $0.003[0.000]$ & $0.003[0.000]$ & $0.002[0.000]$ & 0.260 \\
& $\mathrm{~N}=130$ & $\mathrm{~N}=70$ & $\mathrm{~N}=60$ & {$[0.176]$} \\
OuTSIDEBOARD & $0.122[0.075]$ & $0.084[0.000]$ & $0.168[0.143]$ & {$\left[0.001^{* * *}\right]$} \\
& $\mathrm{N}=130$ & $\mathrm{~N}=70$ & $\mathrm{~N}=60$ & $0.005^{* * *}$ \\
Same industry dummy & 0.392 & 0.457 & 0.317 & 0.102 \\
& $\mathrm{~N}=130$ & $\mathrm{~N}=70$ & $\mathrm{~N}=60$ & \\
\hline
\end{tabular}


Table 3. Cont.

\begin{tabular}{|c|c|c|c|c|}
\hline \multicolumn{5}{|c|}{ Panel B: Characteristics of carve-out subsidiary firms } \\
\hline & Full sample & $\begin{array}{l}\text { Firm with dual } \\
\text { directors }\end{array}$ & $\begin{array}{l}\text { Firm without } \\
\text { dual directors }\end{array}$ & p-Value \\
\hline \multirow[t]{2}{*}{ Ln (Total Assets) } & 8.662 [8.597] & 8.395 [8.157] & $8.974[8.922]$ & $0.029 * *$ \\
\hline & $\mathrm{N}=130$ & $\mathrm{~N}=70$ & $\mathrm{~N}=60$ & {$\left[0.029^{* *}\right]$} \\
\hline \multirow{2}{*}{ Leverage } & 0.580 [0.621] & 0.582 [0.633] & $0.576[0.600]$ & 0.877 \\
\hline & $\mathrm{N}=130$ & $\mathrm{~N}=70$ & $\mathrm{~N}=60$ & [0.869] \\
\hline \multirow[t]{2}{*}{$R O A$} & $0.122[0.115]$ & $0.128[0.123]$ & $0.116[0.105]$ & 0.367 \\
\hline & $\mathrm{N}=130$ & $\mathrm{~N}=70$ & $\mathrm{~N}=60$ & [0.155] \\
\hline \multirow[t]{2}{*}{ CAPEXP } & $0.060[0.037]$ & $0.058[0.031]$ & $0.062[0.042]$ & 0.754 \\
\hline & $\mathrm{N}=130$ & $\mathrm{~N}=70$ & $\mathrm{~N}=60$ & {$[0.305]$} \\
\hline \multirow{2}{*}{ Tangible Asset } & $0.297[0.237]$ & $0.274[0.216]$ & $0.325[0.265]$ & 0.193 \\
\hline & $\mathrm{N}=130$ & $\mathrm{~N}=70$ & $N=60$ & {$[0.124]$} \\
\hline \multirow{2}{*}{ OUTSIDEBOARD } & 0.174 [0.177] & $0.171[0.177]$ & $0.177[0.183]$ & 0.815 \\
\hline & $\mathrm{N}=130$ & $\mathrm{~N}=70$ & $\mathrm{~N}=60$ & [0.897] \\
\hline \multirow{2}{*}{ Subsidiary proceeds } & $0.304[0.176]$ & 0.329 [0.197] & $0.274[0.121]$ & 0.343 \\
\hline & $\mathrm{N}=130$ & $\mathrm{~N}=70$ & $\mathrm{~N}=60$ & {$\left[0.047^{* *}\right]$} \\
\hline \multirow[t]{2}{*}{ Underpricing } & $0.728[0.250]$ & $0.887[0.564]$ & $0.542[0.116]$ & $0.052 *$ \\
\hline & $\mathrm{N}=130$ & $\mathrm{~N}=70$ & $\mathrm{~N}=60$ & {$\left[0.002^{* * *}\right]$} \\
\hline \multirow[t]{2}{*}{ CEO ownership } & $0.040[0.013]$ & $0.048[0.025]$ & $0.031[0.006]$ & 0.149 \\
\hline & $\mathrm{N}=130$ & $\mathrm{~N}=70$ & $\mathrm{~N}=60$ & {$\left[0.008^{* * *}\right]$} \\
\hline \multirow[t]{2}{*}{ CEO Age } & 54 [57] & $54[55]$ & $55[57]$ & 0.536 \\
\hline & $\mathrm{N}=130$ & $N=70$ & $\mathrm{~N}=60$ & {$[0.591]$} \\
\hline Parent ownership right & $0.581[0.575]$ & $0.592[0.589]$ & $0.569[0.573]$ & 0.291 \\
\hline after the IPO & $\mathrm{N}=130$ & $\mathrm{~N}=70$ & $\mathrm{~N}=60$ & {$[0.373]$} \\
\hline \multirow{2}{*}{$\begin{array}{c}\text { Pyramid structure } \\
\text { dummy }\end{array}$} & 0.100 & 0.071 & 0.133 & \multirow{2}{*}{0.241} \\
\hline & $\mathrm{N}=130$ & $\mathrm{~N}=70$ & $N=60$ & \\
\hline \multirow{2}{*}{$\begin{array}{c}\text { Majority control } \\
\text { dummy }\end{array}$} & 0.777 & 0.828 & 0.717 & \multirow{2}{*}{0.127} \\
\hline & $\mathrm{N}=130$ & $\mathrm{~N}=70$ & $N=60$ & \\
\hline
\end{tabular}

\section{Empirical Results}

\subsection{Announcement Period Stock Returns of Parent Firms}

This section presents the results based on the event study approach. We start by examining how a parent firm's stock reacts on the announcement day of equity carve-outs. Panel A of Table 4 shows that AR on the announcement day is $0.89 \%$ with a $p$-value less than 0.01 . The three-, five-, seven-day cumulative abnormal returns are $2.64 \%, 2.83 \%$, and $2.63 \%$, respectively, which is similar to that recorded in the U.S. (Allen and McConnell 1998).

Panel B of Table 4 presents the subsample results. Hypothesis 1 suggests that the stock market will expect these dual directors to enhance the wealth of shareholders in the long run. Our finding that the stock market reacts more favorably to those with dual directors is not statistically different from those without dual directors (e.g., the three-day CAR is $3.4 \%$ vs. $1.6 \%, p=0.124)$.

However, when we take the dual directors' age and position in subsidiaries into consideration, a different picture emerges. We find that the positive reaction to firms with dual directors are mainly driven by those with the dual directors holding CEO positions. Consistent with Hypothesis 2, the CAR $(-2,2)$ is $5.9 \%$ for firms where the dual directors hold CEO position, which is significantly higher than all of the other firms $(1.9 \%)$. This suggests that the stock market expects those in the CEO position to provide those in the internal labor markets with market-based incentives as well as tournament incentives to increase the long-term value of their subsidiaries, and thus ultimately increase the value of their parent firms. 
Table 4. Excess stock returns surrounding announcements of equity carve-outs. AR (abnormal return) and cumulative abnormal returns (CAR) are calculated using the parameters of the five-factor model estimated over the period from -273 to -22 days in which the announcement day is defined as 0. Panel A reports the full sample result. Subsamples are formed according to the presence of dual directors. Panel B compares firms with dual directors and those without. Panel C classifies firms based on the presence of dual directors holding CEO position in the subsidiary firms. Panel D classifies firms based on the presence of young dual directors holding CEO position in the subsidiary firms. Panel E classifies firms based on the presence of dual directors holding the non-CEO position in subsidiary firms. Panel F classifies firms based on the presence of young dual directors holding the non-CEO position in subsidiary firms. The significance of the means is tested using a $t$-statistic. All the variables are winsorized at the top and bottom five percent values. ${ }^{*}, * *$, and ${ }^{* * *}$ indicate significance at the $10 \%, 5 \%$, and $1 \%$ levels, respectively.

\begin{tabular}{|c|c|c|c|c|c|c|}
\hline \multicolumn{7}{|c|}{ Panel A: Full Sample } \\
\hline & Mean & Median & Min. & $\operatorname{Max}$ & S.D. & $N$ \\
\hline \multicolumn{7}{|c|}{ 0: Announcement day } \\
\hline$A R$ at day 0 & $0.89 \%$ & $0.51 \%$ & $-3.29 \%$ & $7.57 \%$ & $2.64 \%$ & 130 \\
\hline$C A R(-1,1)$ & $2.64 \%$ & $0.77 \%$ & $-5.35 \%$ & $18.74 \%$ & $6.07 \%$ & 130 \\
\hline$C A R(-2,2)$ & $2.83 \%$ & $0.24 \%$ & $-6.85 \%$ & $20.73 \%$ & $7.37 \%$ & 130 \\
\hline$C A R(-3,3)$ & $2.63 \%$ & $0.82 \%$ & $-10.70 \%$ & $25.36 \%$ & $8.59 \%$ & 130 \\
\hline
\end{tabular}

Panel B: Classified by dual boards

\begin{tabular}{ccccccccc}
\hline & \multicolumn{3}{c}{ Firms with dual directors } & \multicolumn{2}{c}{ Firms without dual directors } & Difference \\
\hline 0: Announcement day & Mean & $N$ & $p$-Value & Mean & $N$ & $p$-Value & Mean & $p$-Value \\
AR at day 0 & 0.011 & 70 & $0.002^{* * *}$ & 0.007 & 60 & $0.044^{* *}$ & $0.004^{* *}$ & 0.350 \\
CAR $(-1,1)$ & 0.034 & 70 & $0.000^{* * *}$ & 0.016 & 60 & $0.006^{* * *}$ & 0.016 & 0.124 \\
CAR $(-2,2)$ & 0.037 & 70 & $0.001^{* * *}$ & 0.018 & 60 & $0.018^{* *}$ & 0.019 & 0.128 \\
CAR $(-3,3)$ & 0.035 & 70 & $0.005^{* * *}$ & 0.016 & 60 & $0.056^{*}$ & 0.019 & 0.205 \\
\hline
\end{tabular}

Panel C: Classified by CEO positions

\begin{tabular}{|c|c|c|c|c|c|c|c|c|}
\hline \multirow[b]{2}{*}{ 0: Announcement day } & \multicolumn{3}{|c|}{ Firms with dual directors holding CEO position } & \multicolumn{3}{|c|}{ All other firms } & \multicolumn{2}{|c|}{ Difference } \\
\hline & Mean & $N$ & $p$-Value & Mean & $N$ & $p$-Value & Mean & $p$-Value \\
\hline$A R$ at day 0 & 0.018 & 30 & $0.002 * * *$ & 0.006 & 100 & $0.015^{* *}$ & 0.012 & $0.033^{* *}$ \\
\hline$C A R(-1,1)$ & 0.053 & 30 & $0.001 * * *$ & 0.018 & 100 & $0.001^{* * *}$ & 0.035 & $0.005^{* * *}$ \\
\hline$C A R(-2,2)$ & 0.059 & 30 & $0.002 * * *$ & 0.019 & 100 & $0.004^{* * *}$ & 0.040 & $0.009^{* * *}$ \\
\hline$C A R(-3,3)$ & 0.057 & 30 & $0.008^{* * *}$ & 0.017 & 100 & $0.027^{* * *}$ & 0.040 & $0.026^{* *}$ \\
\hline
\end{tabular}

Panel D: Classified by CEO positions and young age

Firms with young dual directors holding CEO position

All other firms

$\begin{array}{cc}\text { p-Value } & \text { Mean } \\ 0.005^{* * *} & 0.006 \\ 0.009^{* * *} & 0.021 \\ 0.010^{* * *} & 0.022 \\ 0.044^{* *} & 0.020\end{array}$

N p-Value

$110 \quad 0.008^{* * *}$

$110 \quad 0.001^{* * *}$

110

110

$0.000 * * *$

$0.007^{* * *}$

Panel E: Classified by non-CEO positions

Firms with dual directors holding non-CEO position

All other firms

\begin{tabular}{ccccccccc} 
0: Announcement day & Mean & $N$ & $p$-Value & Mean & $N$ & $p$-Value & Mean & $p$-Value \\
AR at day 0 & 0.009 & 52 & $0.022^{* *}$ & 0.009 & 78 & $0.003^{* * *}$ & 0.000 & 0.962 \\
CAR $(-1,1)$ & 0.024 & 52 & $0.009 * * *$ & 0.028 & 78 & $0.000^{* * *}$ & -0.004 & 0.724 \\
CAR $(-2,2)$ & 0.025 & 52 & $0.027^{* *}$ & 0.031 & 78 & $0.000^{* * *}$ & -0.006 & 0.664 \\
CAR $(-3,3)$ & 0.016 & 30 & 0.218 & 0.033 & 78 & $0.000^{* * *}$ & -0.018 & 0.245 \\
\hline
\end{tabular}


Table 4. Cont.

\begin{tabular}{|c|c|c|c|c|c|c|c|c|}
\hline \multicolumn{9}{|c|}{ Panel F: Classified by Non-CEO positions \& Young } \\
\hline & \multicolumn{3}{|c|}{$\begin{array}{l}\text { Firms with young dual directors holding non-CEO } \\
\text { position }\end{array}$} & \multicolumn{3}{|c|}{ All other firms } & \multicolumn{2}{|c|}{ Difference } \\
\hline 0: Announcement day & Mean & $N$ & $p$-Value & Mean & $N$ & $p$-Value & Mean & $p$-Value \\
\hline AR at day 0 & 0.011 & 39 & $0.032 * *$ & 0.008 & 91 & $0.002 * * *$ & 0.003 & 0.569 \\
\hline$C A R(-1,1)$ & 0.025 & 39 & $0.027 * *$ & 0.027 & 91 & $0.000 * * *$ & -0.002 & 0.862 \\
\hline$C A R(-2,2)$ & 0.031 & 39 & $0.032 * *$ & 0.027 & 91 & $0.000^{* * *}$ & 0.003 & 0.809 \\
\hline$C A R(-3,3)$ & 0.015 & 39 & 0.345 & 0.031 & 91 & $0.000 * * *$ & -0.016 & 0.326 \\
\hline
\end{tabular}

If the internal labor market really plays an important role, the age structure should also be important. Our Hypothesis 3 predicts that when young dual directors are rewarded as CEOs in subsidiaries, they have a stronger incentive to work harder in order to build long-term reputation. Consistent with this idea, we find that the $C A R(-2,2)$ increased to $6.3 \%$. In contrast to those holding CEO positions, we do not find any robust evidence to prove that the dual directors holding non-CEO positions could create value. While the CAR is also higher for those with dual directors holding non-CEO positions, the difference is not significant. One potential reason is when dual directors cannot take the CEO position, the cost associated with busy boards may cancel out the benefits related to the internal labor markets. Overall, our results indicate that the stock market reacts differently to the types of dual directors.

\subsection{Cross-Sectional Regressions of the Announcement Period CAR}

We formally examine our hypothesis by running the OLS regressions using $C A R(-1,1)$ as a dependent variable. Qualitative similar results were obtained when $C A R(-2,2)$ was used as a dependent variable (see Appendix A Table A2). Model (1) of Table 5 presents a positive coefficient (0.017) for Dual directors, which is not statistically significant. When the dual directors' position in subsidiaries is taken into consideration in Model (2), Dual director holding CEO position carries a positive and significant sign, suggesting that the presence of CEO-dual directors increases the three-day CAR by $3.3 \%$, which is financially important given that the unconditional CAR is only $2.8 \%$. In contrast, Dual director holding non-CEO position in Model (2) shows a negative, although insignificant sign, which supports our Hypothesis 2. In Model (3), we classify dual directors into four types based on the position and age. Consistent with the univariate results, the coefficient of Young dual directors holding CEO position in model (3) increases to $3.7 \%$ and is statistically significant. In sharp contrast with the previous result, we find that the coefficients for all the other types of dual directors are not significant, highlighting the heterogenous functions of the dual directors.

With respect to the control variables, while we find a significant difference in firm characteristics between the firms with dual directors and those without in Table 3, most of the control variables have no bearing on shareholder wealth of the parent firms, except for Same industry dummy and relative size. When the parent firms and their subsidiaries are from the same industry, the stock market reacts negatively. As robustness checks, we also replicated the analysis by (1) computing z-statistics and using the heteroskedasticityconsistent standard errors clustered by the industry (see Appendix A Table A3) (2), further including the year fixed effects (See Appendix A Table A4). The results are qualitatively the same. 
Table 5. Cross-sectional regressions of announcement period CAR. The dependent variable in all regressions is the three-day CAR surrounding the announcement day of the equity carve-out. Dual director takes a value of 1 for firms with at least 1 dual director and 0 otherwise. Dual director holding CEO position takes a value of 1 for firms with at least 1 dual director holding CEO position in the subsidiary firm and 0 otherwise. The dual director holding non-CEO position takes a value of 1 for firms with at least 1 dual director holding non-CEO position in the subsidiary firm and 0 otherwise. Young dual director holding CEO position takes a value of 1 for firms with at least 1 young dual director holding CEO position in the subsidiary firm and 0 otherwise. Old dual director holding CEO position takes a value of 1 for firms with at least 1 dual director holding CEO position (none of the CEO-dual directors are young) in the subsidiary firm, and 0 otherwise. Young dual director holding non-CEO position takes a value of 1 for firms with at least 1 young dual director holding non-CEO position in the subsidiary firm and 0 otherwise. Old dual director holding non-CEO position takes a value of 1 for firms with at least 1 dual director holding non-CEO position (none of the non-CEO-dual directors are young) in the subsidiary firm, and 0 otherwise. Parent ownership right after the IPO is the percentage of shares owned by parent firms right after equity carve-out. OUTSIDEBOARD is the number of outside board members divided by board size. The pyramid structure dummy takes a value of 1 if the parent firms indirectly control the carve-outs and 0 otherwise. Same industry dummy takes a value of 1 if a subsidiary and its parent are in the same industry and 0 otherwise. Parent proceeds is secondary proceeds sold by parent firms divided by their total assets before carve-out. Subsidiary proceeds are primary proceeds raised by a subsidiary firm divided by total assets before carve-out. Leverage is total liabilities scaled by total assets. $R O A$ is operating income divided by total assets. Relative size is the subsidiary's total assets divided by the parent's total assets before carve-outs. The $t$-statistics are in parentheses. ${ }^{*}, * *$, and indicate significance at the $10 \%$ and $5 \%$ levels, respectively.

\begin{tabular}{|c|c|c|c|}
\hline Announcement Period CAR & Model (1) & Model (2) & Model (3) \\
\hline $\begin{array}{l}\text { Dependent variable } \\
\text { Dual director }\end{array}$ & $\begin{array}{c}C A R(-1,1) \\
0.017 \\
(1.35)\end{array}$ & $C A R(-1,1)$ & CAR $(-1,1)$ \\
\hline Dual director holding CEO position & & $\begin{array}{c}0.032 * * \\
(2.50)\end{array}$ & \\
\hline Dual director holding non-CEO position & & $\begin{array}{l}-0.009 \\
(-0.81)\end{array}$ & \\
\hline Young dual director holding CEO position & & & $\begin{array}{c}0.037^{* *} \\
(2.43)\end{array}$ \\
\hline Old dual director holding CEO position & & & $\begin{array}{l}0.023 \\
(1.11)\end{array}$ \\
\hline Young dual director holding non-CEO position & & & $\begin{array}{l}-0.010 \\
(-0.75)\end{array}$ \\
\hline Old dual director holding non-CEO position & & & $\begin{array}{l}-0.005 \\
(-0.29)\end{array}$ \\
\hline $\begin{array}{l}\text { Control variables: } \\
\text { Parent ownership right after the IPO }\end{array}$ & $\begin{array}{l}-0.056 \\
(-1.31)\end{array}$ & $\begin{array}{l}-0.055 \\
(-1.33)\end{array}$ & $\begin{array}{l}-0.055 \\
(-1.30)\end{array}$ \\
\hline OUTSIDEBOARD of the carve-out firms & $\begin{array}{l}0.031 \\
(0.85)\end{array}$ & $\begin{array}{l}0.042 \\
(1.16)\end{array}$ & $\begin{array}{l}0.037 \\
(0.99)\end{array}$ \\
\hline Pyramid structure dummy & $\begin{array}{l}-0.020 \\
(-1.01)\end{array}$ & $\begin{array}{l}-0.028 \\
(-1.45)\end{array}$ & $\begin{array}{l}-0.029 \\
(-1.46)\end{array}$ \\
\hline Same industry dummy & $\begin{array}{l}-0.018 \\
(-1.65)\end{array}$ & $\begin{array}{l}-0.020 \text { * } \\
(-1.87)\end{array}$ & $\begin{array}{l}-0.021 \text { * } \\
(-1.89)\end{array}$ \\
\hline OUTSIDEBOARD of the parent firms & $\begin{array}{l}-0.009 \\
(-0.23)\end{array}$ & $\begin{array}{l}-0.015 \\
(-0.41)\end{array}$ & $\begin{array}{l}-0.012 \\
(-0.31)\end{array}$ \\
\hline Leverage of parent firms & $\begin{array}{l}0.050 \\
(1.46)\end{array}$ & $\begin{array}{l}0.042 \\
(1.24)\end{array}$ & $\begin{array}{l}0.042 \\
(1.24)\end{array}$ \\
\hline ROA of parent firms & $\begin{array}{l}-0.116 \\
(-0.79)\end{array}$ & $\begin{array}{l}-0.077 \\
(-0.53)\end{array}$ & $\begin{array}{l}-0.083 \\
(-0.57)\end{array}$ \\
\hline
\end{tabular}


Table 5. Cont.

\begin{tabular}{|c|c|c|c|}
\hline Announcement Period CAR & Model (1) & Model (2) & Model (3) \\
\hline \multirow[t]{2}{*}{ Relative size } & 0.193 * & 0.186 * & $0.192 *$ \\
\hline & $(1.91)$ & $(1.87)$ & $(1.90)$ \\
\hline \multirow[t]{2}{*}{ Parent proceeds } & 0.903 & 0.710 & 0.716 \\
\hline & $(0.94)$ & $(0.76)$ & $(0.75)$ \\
\hline \multirow[t]{2}{*}{ Subsidiary proceeds } & 0.016 & 0.022 & 0.022 \\
\hline & $(0.91)$ & $(1.27)$ & $(1.20)$ \\
\hline \multirow[t]{2}{*}{ Constant } & 0.011 & 0.018 & 0.018 \\
\hline & $(0.26)$ & $(0.47)$ & $(0.46)$ \\
\hline $\mathrm{N}$ & 130 & 130 & 130 \\
\hline R2 & 0.054 & 0.088 & 0.075 \\
\hline
\end{tabular}

\subsection{Post-Carve-Out Performance}

While the results in the previous sections support Hypotheses 2 and 3, we conduct additional analyses to examine their assumptions. Our hypothesis assumes that dual directors can enhance their parent firms' shareholder wealth of if they can improve the long-term performance of subsidiaries and the parent firms keep their majority stake in the subsidiaries. Indeed, more than $65 \%$ of our sample firms hold more than $50 \%$ ownership of their subsidiaries, and more than $80 \%$ of the parent firms are still the largest shareholders five years later.

We formally test our assumption by examining three- and five-year performances of the carve-out firms. There is a concern that the unobservable characteristics of firms that appoint dual directors differ from those that do not, which may also affect the post-carveout period performance. To overcome this concern, a matching procedure is used. For each of the firms with at least one dual director, the nearest matching firm is chosen from the other firms based on the propensity score calculated by probit estimation. Motivated by the different firm characteristics in Panel B of Table 3, carve-out subsidiaries' characteristics, including CEO Age, Majority control dummy, Underpricing (difference between initial price and offering price divided by offering price), CEO ownership, Ln (Total Assets), Leverage, CAPEXP, and Tangible Asset, are used to compute the covariate in the probit estimation. If the matching is successful, there should be a small difference in the variables used to compute the covariate between the treatment and the matched groups. Untabulated results show that the firms' (both parent firms and subsidiaries) characteristics between treatment and control groups become insignificant for all the observable variables included in Table 3, or the matching is successful.

To accurately measure the effect of dual directors, we employ two performance variables: $R O A$ and Tobin's $Q$ (total capitalization and book value of liabilities scaled by book value of assets). $R O A(0,3)$ is the average $R O A$ from the 0 year to the +3 year, where 0 indicates the carve-out year. $\operatorname{Adj} \operatorname{ROA}(0,3)$ is the average of the industry-mean adjusted $R O A$ from the 0 year to the +3 year. Tobin's $Q(0,3)$ is the average Tobin's $Q$ from the 0 year to the +3 year. Adj Tobin's $Q(0,3)$ is the average of the industry-mean adjusted Tobin's $Q$ from the 0 year to the +3 year. We observe similar results when we extend the sample period to five years after the carve-outs (see Appendix A Table A5).

Table 6 presents the results of long-term firm performance after carve-outs between firms with dual directors and their control firms. Panel A presents the respective results between firms whose dual directors are holding the CEO position and their control firms. While we do not find any significant difference, both ROA and Adjusted ROA are higher for the firms whose dual directors were holding the CEO position. In terms of Tobin's $Q$, there is no significant difference between the two groups. Meanwhile, Panel B of Table 6 shows that young dual directors holding the CEO position significantly outperformed their counterparts. The $\operatorname{ROA}(\mathbf{0}, 3)$ is $11 \%$ for firms whose young dual directors were holding the CEO position, which is significantly higher than that of the control groups $(5.4 \%, t=2.03)$. With respect to Tobin's $Q$, we also find that firms with young dual directors holding 
the CEO position present superior performances than their counterparts (Adj Tobin's Q: 1.356 vs. $0.463, t=2.06$ ), suggesting that the CEO position successfully motivated young dual directors to enhance shareholders' wealth. However, when the subsample was divided by the number of dual directors holding non-CEO positions, consistent with the results of a previous event study, we also do not find robust evidence proving that dual directors can create shareholder value when not holding the CEO position, highlighting the heterogeneity of dual directors.

Table 6. Dual directors and subsidiaries' performance after carve-outs. This table reports propensity score matching results of subsidiaries' performance after carve-outs. It presents a comparison between firms with dual directors and those without. For each firm with at least one dual director, one nearest matching firm is chosen from all the other firms based on the propensity score by probit estimation. Carve-out subsidiaries' characteristics including CEO Age, the Majority control dummy, Underpricing, CEO ownership, Ln (Total Assets), Leverage, CAPEXP, Tangible Asset, are used to compute the covariate in the probit estimation. $R O A(0,3)$ is the average $R O A$ from the 0 year to the +3 year. $\operatorname{Adj} R O A(0,3)$ is the average of the industry-mean adjusted $R O A$ from the 0 year to the +3 year. Tobin's $Q(0,3)$ is the average Tobin's $Q$ from the 0 year the to +3 year. Adj Tobin's $Q(0,3)$ is the average of the industry-mean adjusted Tobin's $Q$ from the 0 year to the +3 year. t-statistics are used for the mean difference test. ${ }^{*}, *$ indicate significance at the $10 \%, 5 \%$ levels, respectively.

\begin{tabular}{|c|c|c|c|c|c|}
\hline \multicolumn{6}{|c|}{ Panel A: Classified by CEO positions } \\
\hline & \multicolumn{2}{|c|}{$\begin{array}{l}\text { Firms with dual directors holding } \\
\text { CEO position }\end{array}$} & \multicolumn{2}{|c|}{ All other firms } & \multirow[t]{2}{*}{$t$-statistics } \\
\hline \multicolumn{5}{|l|}{ 0: Carve-out year } & \\
\hline$R O A(0,3)$ & 0.091 & $\mathrm{~N}=30$ & 0.064 & $\mathrm{~N}=30$ & 1.29 \\
\hline Adj $R O A(0,3)$ & 0.041 & $\mathrm{~N}=30$ & 0.014 & $\mathrm{~N}=30$ & 1.32 \\
\hline Tobin's $Q(0,3)$ & 2.366 & $\mathrm{~N}=30$ & 2.451 & $\mathrm{~N}=30$ & -0.17 \\
\hline Adj Tobin's $Q(0,3)$ & 1.033 & $\mathrm{~N}=30$ & 1.007 & $\mathrm{~N}=30$ & 0.05 \\
\hline \multicolumn{6}{|c|}{ Panel B: Classified by CEO positions and Young } \\
\hline & \multicolumn{2}{|c|}{$\begin{array}{l}\text { Firms with young dual directors } \\
\text { holding CEO position }\end{array}$} & \multicolumn{2}{|c|}{ All other firms } & t-statistics \\
\hline \multicolumn{6}{|l|}{ 0: Carve-out year } \\
\hline $\operatorname{ROA}(0,3)$ & 0.110 & $\mathrm{~N}=20$ & 0.054 & $\mathrm{~N}=20$ & $2.03 * *$ \\
\hline Adj ROA $(0,3)$ & 0.060 & $\mathrm{~N}=20$ & 0.007 & $\mathrm{~N}=20$ & $1.92 *$ \\
\hline Tobin's $Q(0,3)$ & 2.727 & $\mathrm{~N}=20$ & 1.705 & $\mathrm{~N}=20$ & $2.06^{* *}$ \\
\hline Adj Tobin's $Q(0,3)$ & 1.365 & $\mathrm{~N}=20$ & 0.463 & $\mathrm{~N}=20$ & $2.06^{* *}$ \\
\hline \multicolumn{6}{|c|}{ Panel C: Classified by non-CEO positions } \\
\hline & \multicolumn{2}{|c|}{$\begin{array}{l}\text { Firms with dual directors holding } \\
\text { non-CEO position }\end{array}$} & \multicolumn{2}{|c|}{ All other firms } & t-statistics \\
\hline \multicolumn{6}{|l|}{ 0: Carve-out year } \\
\hline$R O A(0,3)$ & 0.086 & $\mathrm{~N}=52$ & 0.064 & $\mathrm{~N}=52$ & 1.22 \\
\hline Adj ROA $(0,3)$ & 0.038 & $\mathrm{~N}=52$ & 0.012 & $\mathrm{~N}=52$ & 1.44 \\
\hline Tobin's $Q(0,3)$ & 2.406 & $N=52$ & 2.210 & $\mathrm{~N}=52$ & 0.44 \\
\hline Adj Tobin's $Q(0,3)$ & 1.040 & $\mathrm{~N}=52$ & 0.817 & $\mathrm{~N}=52$ & 0.53 \\
\hline \multicolumn{6}{|c|}{ Panel D: Classified by non-CEO positions adn Young } \\
\hline & \multicolumn{2}{|c|}{$\begin{array}{l}\text { Firms with young dual directors } \\
\text { holding non-CEO position }\end{array}$} & \multicolumn{2}{|c|}{ All other firms } & t-statistics \\
\hline \multicolumn{6}{|l|}{ 0: Carve-out year } \\
\hline$R O A(0,3)$ & 0.085 & $\mathrm{~N}=39$ & 0.090 & $\mathrm{~N}=39$ & -0.18 \\
\hline $\operatorname{Adj} \operatorname{ROA}(0,3)$ & 0.035 & $\mathrm{~N}=39$ & 0.037 & $\mathrm{~N}=39$ & -0.08 \\
\hline Tobin's $Q(0,3)$ & 2.598 & $\mathrm{~N}=39$ & 2.664 & $\mathrm{~N}=39$ & -0.13 \\
\hline Adj Tobin's $Q(0,3)$ & 1.211 & $N=39$ & 1.226 & $\mathrm{~N}=39$ & -0.03 \\
\hline
\end{tabular}




\subsection{Further Analysis}

One can argue that there are other factors driving the positive abnormal return. In the case that young talented directors were sent to major subsidiary, the positive market reaction might be attributed to relative importance of the subsidiary, rather than dual directorship. To address this concern, we first divide our sample into two subsamples based on relative size, and then restrict the analysis to those in the bottom half. Even among the relatively less important subsidiaries, Young dual directors holding CEO position have a positive and significant coefficient, with the coefficient in Table 5 increasing from 0.036 to 0.074 . Next, we run logit regression to explore the determinants of the dependent variable Young dual directors holding CEO position. While Model (1) in Table 7 presents a positive coefficient (4.880) for Relative size, it is not statistically significant. ${ }^{6}$ In contrast, INSIDEBOARD (the proportion of the inside board of the parent firms) carries a positive and significant sign, suggesting that firms characterized by insider-dominated boards are more likely to send young members to subsidiaries.

Table 7. Determinants of young dual directors holding the CEO position. This table presents the results of logit regressions of young dual directors holding the CEO position. The dependent variable is Young dual director holding CEO position, which takes a value of 1 for firms with at least 1 young dual director holding the CEO position in the subsidiary firm and 0 otherwise. INSIDEBOARD is the proportion of inside boards of parent firms. Relative size is the subsidiary's total assets divided by the parent's total assets before carve-outs. See Appendix A Table A1 for variable definition. z-statistics computed using heteroskedasticity-consistent standard errors (clustered by industry) are in parentheses. ${ }^{*}{ }^{* *}$ indicate significance at the $10 \%, 5 \%$ levels, respectively.

\begin{tabular}{ccc}
\hline & Model (1) & Model (2) \\
\hline \multirow{2}{*}{ INSIDEBOARD of parent firms } & Logit & Logit \\
Relative size & $5.109^{* *}$ & $7.423^{* *}$ \\
& $(2.04)$ & $(2.01)$ \\
Pyramid structure dummy & 4.880 & 5.972 \\
& $(0.84)$ & $(0.75)$ \\
Same industry dummy & 1.081 & 1.629 \\
& $(1.50)$ & $(1.24)$ \\
Parent Leverage & 0.760 & 0.575 \\
& $(1.27)$ & $(0.91)$ \\
Parent ROA & -1.254 & -1.686 \\
& $(-0.84)$ & $(-0.78)$ \\
Parent proceeds & -5.114 & -11.296 \\
& $(-0.99)$ & $(-1.26)$ \\
Subsidiary proceeds & 7.327 & -23.625 \\
& $(0.14)$ & $(-0.55)$ \\
Constant & 0.624 & 0.745 \\
& $(0.65)$ & $(0.47)$ \\
Industry dummy & $-6.289 *$ & $-8.228^{*}$ \\
Year dummy & $(-1.82)$ & $(-1.85)$ \\
N & No & Yes \\
& No & Yes \\
\end{tabular}

Our hypotheses assume that the CEO position in subsidiaries provides a big tournament incentive to those in the internal labor markets. To examine this assumption, we replicate the analysis in Table 5 by adding two variables: $C E O$ Tenure, and the interaction term between Young dual director holding CEO position and CEO Tenure. The internal labor market hypothesis predicts that newly appointed CEOs are more likely to enhance shareholder wealth. Consistent with this view, Table 8 engenders positive coefficients on Young dual director holding CEO position and negative coefficients on the interaction term. The estimated coefficients indicate that if young CEO dual directors were appointed one year (five years) before the equity carve-out, the three-day CAR is $6.9 \%(2.5 \%)$. Consis- 
tent with the long-term career concern hypothesis that newly appointed CEOs have an incentive to improve long-term performance to create good reputation for the future, CEO Tenure carries a negative and significant sign. ${ }^{7}$ The internal labor market hypothesis further predicts that young CEO dual directors are less likely to pursue short-term profits for the purpose of building reputation in the short run because the information asymmetry is less severe for them. Consistent with this idea, the negative coefficients on the interaction term suggests that dual directorships strengthen the long-term career concern effect.

Table 8. Internal labor market and career concerns. This table presents the results of OLS regressions of CAR surrounding the announcement day of the equity carve-out. Young dual director holding CEO position takes a value of 1 for firms with at least 1 young dual director holding the CEO position in the subsidiary firm and 0 otherwise. CEO Tenure is the number of years for which the incumbent CEO of the subsidiary takes the position. See Appendix A Table A1 for the variable definition. The $t$-statistics are in parentheses. ${ }^{* * *}$, and ${ }^{* * *}$ indicate significance at the $10 \%, 5 \%$, and $1 \%$ levels, respectively.

\begin{tabular}{cccc}
\hline & Model (1) & Model (2) & Model (3) \\
\hline Young dual director holding CEO position & $0.082^{* * *}$ & $0.092^{* * *}$ & $0.075^{* *}$ \\
Young dual director holding CEO position & $(3.56)$ & $(3.17)$ & $(2.11)$ \\
$\times$ CEO Tenure & $-0.011^{* * *}$ & $-0.012^{* *}$ & -0.009 \\
& $(-2.57)$ & $(-2.27)$ & $(-1.41)$ \\
CEO Tenure & $-0.003^{* *}$ & $-0.003^{*}$ & $-0.003^{*}$ \\
Control variables & $(-2.29)$ & $(-1.80)$ & $(-1.66)$ \\
$\mathrm{N}$ & Yes & Yes & Yes \\
R2 & 130 & 130 & 130 \\
& 0.185 & 0.133 & 0.043 \\
\hline
\end{tabular}

Thus far, we used 60 as a cutoff value to define the young director. As a robustness check, we replicate the analyses by using 65 as the cutoff value and the results are presented in Table 9. Young dual director holding CEO position consistently carries positive and significant signs in Model (1) to Model (3). Overall, our results are robust to control for alternative stories and a different definition of young directors.

Table 9. Different cutoffs of young dual directors holding the CEO position. This table presents the results of OLS regressions of CAR surrounding the announcement day of the equity carve-out. Young dual director holding CEO position takes a value of 1 for firms with at least 1 young dual director holding the CEO position in the subsidiary firm and 0 otherwise. We use 65 years as the cutoff value. See Appendix A Table A1 for the variable definition. The $t$-statistics are in parentheses. ${ }^{* *}$, and ${ }^{* *}$ indicate significance at the $5 \%$, and $1 \%$ levels, respectively.

\begin{tabular}{cccc}
\hline Announcement Period CAR & Model (1) & Model (2) & Model (3) \\
\hline & CAR $(-1,1)$ & CAR $(-2,2)$ & CAR $(-3,3)$ \\
\hline Young dual director holding CEO position & $0.041^{* * *}$ & $0.046^{* * *}$ & $0.044^{* *}$ \\
Control variables & $(3.19)$ & $(2.92)$ & $(2.29)$ \\
N & Yes & Yes & Yes \\
R2 & 130 & 130 & 130 \\
& 0.116 & 0.088 & 0.022 \\
\hline
\end{tabular}

\section{Conclusions}

A burgeoning literature suggests that parent firms tend to retain long-run relationships with carve-out firms (Desai et al. 2011; Otsubo 2013; Perotti and Rossetto 2007). An important feature of the parent-subsidiary relationship after carve-outs is the presence of parent-appointed directors, the function of which has not yet been well examined. 
We use Japanese equity carve-outs to examine the benefits from dual directors and find that when dual directors hold the CEO positions in carve-out subsidiaries, internal labor market disciplines and long-term career concerns motivate them to create value for both the subsidiaries and parent companies.

Our first hypothesis argues that the stock market will expect these dual directors to enhance the wealth of shareholders in the long run. However, inconsistent with the hypothesis, we find that the stock market's reaction is not statistically different between those with dual directors and those without. However, when we take the dual directors' age and position in the subsidiaries into consideration, a different picture emerges. We find that the positive reaction to firms with dual directors are mainly driven by those with dual directors holding CEO positions. This finding is consistent with our second hypothesis that the CEO position provides those in the internal labor markets with market-based incentives as well as tournament incentives. We also find that in companies where dual directors, especially relatively younger ones, hold the CEO position, there is a significant improvement in the performance of the firms (ROA and Tobin's $Q)$. Overall, our results suggest that dual directors create value for both carve-out and parent companies, and that the CEO position provides younger employees in the internal labor markets with a strong incentive to work hard.

To the best of our knowledge, this is the first study to investigate the dynamics of a parent-subsidiary relationship after carve-outs by focusing on the functions of dual directors. Our results are consistent with the findings of Coles et al. (2014) and Coles and Uchida (2018) that the insider-dominated board can also increase firm value when the internal labor market discipline works well. We documented that young CEOs appointed from the internal labor market care would more about their long-term career, and thus can enhance shareholder wealth of both parent and subsidiary firms. Furthermore, our findings also highlight that many firms conduct carve-outs for motivations different from strategic refocusing, a phenomenon largely ignored by previous studies.

Funding: This research was supported by JSPS KAHENHI (Grants-in-Aid for Scientific Research), Grant Number 19K23215 and 20K13535.

Data Availability Statement: No new data were created or analyzed. Data sharing is not applicable to this manuscript.

Acknowledgments: We acknowledge the 2021 VSBF Co-chairs and Editor-In-Chief for providing us with an opportunity to submit this paper in this well-reputed journal. The author thanks kazuo Yamada and Wouter Torsin for their helpful comments. I gratefully acknowledge the great supports by the research office of the Ritsumeikan Asia Pacific University. Finally, this research is dedicated to my beloved mother, Ruzhen Chen.

Conflicts of Interest: The author declares no conflict of interest.

\section{Appendix A}

Table A1. Variable definition.

Dual director

Dummy variable that takes a value of 1 for firms with at least 1 dual director and 0 otherwise

Dual director holding CEO position

Dummy variable that takes a value of 1 for firms with at least 1 dual director holding the CEO position in the subsidiary firm and 0 otherwise

Young dual director holding CEO position

Dummy variable that takes a value of 1 for firms with at least 1 young dual director holding the CEO position in the subsidiary firm and 0 otherwise

Dummy variable that takes a value of 1 for firms with at least 1 dual director

holding the CEO position (none of the CEO-dual directors are young) in the
Old dual director holding CEO position subsidiary firm, and 0 otherwise

Dummy variable that takes a value of 1 for firms with at least 1 dual director holding the Non-CEO position in the subsidiary firm and 0 otherwise 
Table A1. Cont.

\begin{tabular}{|c|c|}
\hline $\begin{array}{l}\text { Young dual director holding Non-CEO } \\
\text { position }\end{array}$ & $\begin{array}{l}\text { Dummy variable that takes a value of } 1 \text { for firms with at least } 1 \text { young dual } \\
\text { director holding the Non-CEO position in the subsidiary firm and } 0 \text { otherwise }\end{array}$ \\
\hline Old dual director holding Non-CEO position & $\begin{array}{l}\text { Dummy variable that takes a value of } 1 \text { for firms with at least } 1 \text { dual director } \\
\text { holding the non-CEO position (none of the non-CEO-dual directors are young) } \\
\text { in the subsidiary firm, and } 0 \text { otherwise }\end{array}$ \\
\hline Ln (Total Assets) & Natural logarithm of total assets \\
\hline Leverage & Leverage is total liabilities scaled by total assets \\
\hline$R O A$ & Operating income divided by total assets \\
\hline Relative size & Subsidiary's total assets divided by parent's total assets before carve-out \\
\hline Parent proceeds & $\begin{array}{c}\text { Secondary proceeds sold by parent firms divided by parent's total assets before } \\
\text { carve-out }\end{array}$ \\
\hline Subsidiary proceeds & $\begin{array}{l}\text { Primary proceeds raised by a subsidiary firm divided by the total assets of the } \\
\text { subsidiary firm before carve-out }\end{array}$ \\
\hline OUTSIDEBOARD & Number of outside board members divided by board size \\
\hline INSIDEBOARD & Number of inside board members divided by board size \\
\hline CAPEXP & Capital expenditures divided by total assets \\
\hline Tangible Asset & Tangible assets over total assets \\
\hline Underpricing & Percentage difference between initial price and offering price \\
\hline CEO ownership & Percentage of shares owned by the CEOs \\
\hline CEO age & Age of CEOs of subsidiaries in the carve-out year \\
\hline Parent ownership right after the IPO & Percentage of shares owned by parent firm right after equity carve-out \\
\hline Pyramid structure dummy & $\begin{array}{c}\text { Dummy variable that takes on a value of } 1 \text { if the parent firms indirectly control } \\
\text { the carve-out firms and } 0 \text { otherwise }\end{array}$ \\
\hline Majority control dummy & $\begin{array}{l}\text { Dummy variable that takes on a value of } 1 \text { if the parent ownership right after the } \\
\text { IPO is more than } 50 \% \text { and } 0 \text { otherwise }\end{array}$ \\
\hline Tobin' $Q$ & Total capitalization and book value of liabilities scaled by book value of assets \\
\hline
\end{tabular}

Table A2. Cross-Sectional regressions of announcement period CAR. The dependent variable in all regressions is the five-day CAR surrounding the announcement day of the equity carve-out. ** indicate significance at the $5 \%$ levels, respectively.

\begin{tabular}{|c|c|c|c|}
\hline & Model (1) & Model (2) & Model (3) \\
\hline Dependent variable & $C A R(-2,2)$ & $C A R(-2,2)$ & $C A R(-2,2)$ \\
\hline Dual director & $\begin{array}{l}0.015 \\
(1.03)\end{array}$ & & \\
\hline Dual director holding CEO position & & $\begin{array}{c}0.036^{* *} \\
(2.22)\end{array}$ & \\
\hline Dual director holding non-CEO position & & $\begin{array}{l}-0.013 \\
(-0.93)\end{array}$ & \\
\hline Young dual director holding CEO position & & & $\begin{array}{c}0.041^{* *} \\
(2.20)\end{array}$ \\
\hline Old dual director holding CEO position & & & $\begin{array}{l}0.019 \\
(0.75)\end{array}$ \\
\hline Young dual director holding non-CEO position & & & $\begin{array}{l}-0.008 \\
(-0.53)\end{array}$ \\
\hline Old dual director holding non-CEO position & & & $\begin{array}{l}-0.022 \\
(-0.93)\end{array}$ \\
\hline Control variables: & Yes & Yes & Yes \\
\hline $\mathrm{N}$ & 130 & 130 & 130 \\
\hline $\mathrm{R} 2$ & 0.031 & 0.063 & 0.055 \\
\hline
\end{tabular}


Table A3. Cross-sectional regressions of announcement period CAR. The dependent variable in all regressions is the three-day CAR surrounding the announcement day of the equity carve-out. $z$-statistics computed using heteroskedasticity-consistent standard errors (clustered by industry) are in parentheses. *, and ** indicate significance at the $10 \%$ and $5 \%$ levels, respectively.

\begin{tabular}{|c|c|c|c|}
\hline & Model (1) & Model (2) & Model (3) \\
\hline Dependent variable & CAR $(-1,1)$ & $C A R(-1,1)$ & $\operatorname{CAR}(-1,1)$ \\
\hline \multirow[t]{2}{*}{ Dual director } & 0.017 & & \\
\hline & $(1.14)$ & & \\
\hline \multirow[t]{2}{*}{ Dual director holding CEO position } & & $0.032 * *$ & \\
\hline & & $(2.33)$ & \\
\hline \multirow{2}{*}{ Dual director holding non-CEO position } & & -0.009 & \\
\hline & & $(-0.89)$ & \\
\hline \multirow[t]{2}{*}{ Young dual director holding CEO position } & & & 0.037 * \\
\hline & & & $(1.75)$ \\
\hline \multirow[t]{2}{*}{ Old dual director holding CEO position } & & & 0.023 \\
\hline & & & $(1.28)$ \\
\hline \multirow[t]{2}{*}{ Young dual director holding non-CEO position } & & & -0.010 \\
\hline & & & $(-0.78)$ \\
\hline \multirow[t]{2}{*}{ Old dual director holding non-CEO position } & & & -0.005 \\
\hline & & & $(-0.26)$ \\
\hline Control variables: & Yes & Yes & Yes \\
\hline $\mathrm{N}$ & 130 & 130 & 130 \\
\hline R2 & 0.054 & 0.088 & 0.075 \\
\hline
\end{tabular}

Table A4. Cross-sectional regressions of announcement period CAR. The dependent variable in all regressions is the three-day CAR surrounding the announcement day of the equity carve-out. Z-statistics computed using heteroskedasticity-consistent standard errors (clustered by industry) are in parentheses. Year dummies are also included. **, and *** indicate significance at the $5 \%$, and $1 \%$ levels, respectively.

\begin{tabular}{|c|c|c|c|}
\hline & Model (1) & Model (2) & Model (3) \\
\hline Dependent variable & $C A R(-1,1)$ & CAR $(-1,1)$ & CAR $(-1,1)$ \\
\hline Dual director & $\begin{array}{l}0.014 \\
(0.94)\end{array}$ & & \\
\hline Dual director holding CEO position & & $\begin{array}{c}0.036^{* * *} \\
(3.12)\end{array}$ & \\
\hline Dual director holding non-CEO position & & $\begin{array}{l}-0.015 \\
(-1.52)\end{array}$ & \\
\hline Young dual director holding CEO position & & & $\begin{array}{c}0.041 \text { ** } \\
(2.13)\end{array}$ \\
\hline Old dual director holding CEO position & & & $\begin{array}{l}0.027 \\
(1.55)\end{array}$ \\
\hline Young dual director holding non-CEO position & & & $\begin{array}{l}-0.015 \\
(-1.28)\end{array}$ \\
\hline Old dual director holding non-CEO position & & & $\begin{array}{l}-0.011 \\
(-0.51)\end{array}$ \\
\hline Control variables: & Yes & Yes & Yes \\
\hline Year dummy & Yes & Yes & Yes \\
\hline $\mathrm{N}$ & 130 & 130 & 130 \\
\hline $\mathrm{R} 2$ & 0.015 & 0.076 & 0.061 \\
\hline
\end{tabular}


Table A5. Dual directors and subsidiaries' performance after carve-out. * and ${ }^{* *}$ indicate significance at the $10 \%$ and $5 \%$ levels, respectively.

\begin{tabular}{|c|c|c|c|c|c|}
\hline \multicolumn{6}{|c|}{ Panel A: Classified by CEO positions } \\
\hline & \multicolumn{2}{|c|}{$\begin{array}{l}\text { Firms with dual directors holding } \\
\text { CEO position }\end{array}$} & \multicolumn{2}{|c|}{ All other firms } & t-statistics \\
\hline \multicolumn{6}{|l|}{ 0: Carve-out year } \\
\hline$R O A(0,5)$ & 0.083 & $\mathrm{~N}=30$ & 0.062 & $\mathrm{~N}=30$ & 1.07 \\
\hline $\operatorname{Adj} \operatorname{ROA}(0,5)$ & 0.036 & $\mathrm{~N}=30$ & 0.012 & $\mathrm{~N}=30$ & 1.19 \\
\hline Tobin $Q(0,5)$ & 2.208 & $\mathrm{~N}=30$ & 2.214 & $\mathrm{~N}=30$ & -0.01 \\
\hline Adj Tobin $Q(0,5)$ & 0.887 & $\mathrm{~N}=30$ & 0.827 & $\mathrm{~N}=30$ & 0.16 \\
\hline \multicolumn{6}{|c|}{ Panel B: Classified by CEO positions and Young } \\
\hline & \multicolumn{2}{|c|}{$\begin{array}{c}\text { Firms with Young dual directors } \\
\text { holding CEO position }\end{array}$} & \multicolumn{2}{|c|}{ All other firms } & t-statistics \\
\hline \multicolumn{6}{|l|}{ 0: Carve-out year } \\
\hline$R O A(0,5)$ & 0.100 & $\mathrm{~N}=20$ & 0.051 & $\mathrm{~N}=20$ & 1.94 * \\
\hline $\operatorname{Adj} \operatorname{ROA}(0,5)$ & 0.051 & $\mathrm{~N}=20$ & 0.004 & $\mathrm{~N}=20$ & $1.83 *$ \\
\hline Tobin $Q(0,5)$ & 2.532 & $\mathrm{~N}=20$ & 1.573 & $\mathrm{~N}=20$ & $2.45^{* *}$ \\
\hline Adj Tobin $Q(0,5)$ & 1.162 & $\mathrm{~N}=20$ & 0.365 & $\mathrm{~N}=20$ & $2.28^{* *}$ \\
\hline \multicolumn{6}{|c|}{ Panel C: Classified by non-CEO positions } \\
\hline & \multicolumn{2}{|c|}{$\begin{array}{l}\text { Firms with dual directors holding } \\
\text { non-CEO position }\end{array}$} & \multicolumn{2}{|c|}{ All other firms } & t-statistics \\
\hline \multicolumn{6}{|l|}{ 0: Carve-out year } \\
\hline$R O A(0,5)$ & 0.080 & $\mathrm{~N}=52$ & 0.056 & $\mathrm{~N}=52$ & 1.33 \\
\hline Adj ROA $(0,5)$ & 0.034 & $\mathrm{~N}=52$ & 0.005 & $\mathrm{~N}=52$ & 1.58 \\
\hline Tobin $Q(0,5)$ & 2.219 & $\mathrm{~N}=52$ & 2.072 & $\mathrm{~N}=52$ & 0.40 \\
\hline Adj Tobin $Q(0,5)$ & 0.889 & $\mathrm{~N}=52$ & 0.725 & $\mathrm{~N}=52$ & 0.47 \\
\hline \multicolumn{6}{|c|}{ Panel D: Classified by non-CEO positions and Young } \\
\hline & \multicolumn{2}{|c|}{$\begin{array}{l}\text { Firms with Young dual directors } \\
\quad \text { holding Non-CEO position }\end{array}$} & \multicolumn{2}{|c|}{ All the other firms } & t-statistics \\
\hline \multicolumn{6}{|l|}{ 0: Carve-out year } \\
\hline$R O A(0,5)$ & 0.079 & $N=39$ & 0.079 & $\mathrm{~N}=39$ & 0.03 \\
\hline $\operatorname{Adj} \operatorname{ROA}(0,5)$ & 0.030 & $\mathrm{~N}=39$ & 0.028 & $\mathrm{~N}=39$ & 0.11 \\
\hline Tobin $Q(0,5)$ & 2.416 & $\mathrm{~N}=39$ & 2.556 & $\mathrm{~N}=39$ & -0.31 \\
\hline Adj Tobin $Q(0,5)$ & 1.054 & $\mathrm{~N}=39$ & 1.117 & $\mathrm{~N}=39$ & -0.16 \\
\hline
\end{tabular}

\section{Notes}

1 In a spin-off, which is different from an equity carve-out, the shareholders of the parent companies are given a pro-rata distribution of the shares of the subsidiaries being divested. This creates a stand-alone company that is relatively independent of the parent firm.

2 Parent firms can exit from carve-out firms through spin-offs, secondary offerings, and M\&A.

3 The two subsidiaries have two dual directors who share the CEO position.

4 Even in the case of spin-offs, while the parent-subsidiary relationship is terminated, parent firms can still appoint their own directors to serve simultaneously on the boards of their spinoff firms (Feldman 2016).

5 We use 60 as a cutoff value because the mean (median) age of Japanese CEOs is 59 (61) years in Coles and Uchida (2018).

6 Qualitatively similar result is obtained when we further control year and industry fixed effects, as presented in Model (2) of Table 7.

7 About $60 \%(75 \%)$ of the young CEO dual directors were appointed three (five) years before the carve-out.

\section{References}

Ahn, Seoungpil, and Mark D. Walker. 2007. Corporate governance and the spinoff decision. Journal of Corporate Finance 13: 76-93. [CrossRef]

Allen, Jeffrey W. 1998. Capital markets and corporate structure: The equity carve-outs of Thermo Electron. Journal of Financial Economics 48: 99-124. [CrossRef] 
Allen, Jeffrey W., and John J. McConnell. 1998. Equity carve-outs and managerial discretion. Journal of Finance 53: 163-86. [CrossRef]

Aron, Debra J. 1991. Using the capital market as a monitor: Corporate spinoffs in an agency framework. Rand Journal of Economics 22: 505-18. [CrossRef]

Atanasov, Vladimir, Audra Boone, and David Haushalter. 2010. Is there shareholder expropriation in the United States? An analysis of publicly traded subsidiaries. Journal of Financial and Quantitative Analysis 45: 1-26. [CrossRef]

Basu, Sudipta, Lee-Seok Hwang, Toshiaki Mitsudome, and Joseph Weintrop. 2007. Corporate governance, top executive compensation and firm performance in Japan. Pacific-Basin Finance Journal 15: 56-79. [CrossRef]

Berger, Philip G., and Eli Ofek. 1995. Diversification's effect on firm value. Journal of Financial Economics 37: 39-65. [CrossRef]

Bergh, Donald D., Richard A. Johnson, and Rocki-Lee Dewitt. 2008. Restructuring through spin-off or sell-off: Transforming information asymmetries into financial gain. Strategic Management Journal 29: 133-48. [CrossRef]

Boone, Audra, David Haushalter, and Wayne Mikkelson. 2003. An investigation of the gains from specialized equity claims. Financial Management 32: 67-83. [CrossRef]

Brickley, James A., James S. Linck, and Jeffrey L. Coles. 1999. What happens to CEOs after they retire? New evidence on career concerns, horizon problems, and CEO incentives. Journal of Financial Economics 52: 341-77. [CrossRef]

Bugeja, Martin, Raymond Da Silva Rosa, and Andrew Lee. 2009. The impact of director reputation and performance on the turnover and board seats of target firm directors. Journal of Business Finance $\mathcal{E}$ Accounting 36: 185-209.

Burch, Timothy R., and Vikram Nanda. 2003. Divisional diversity and the conglomerate discount: Evidence from spinoffs. Journal of Financial Economics 70: 69-98. [CrossRef]

Chahine, Salim, and Mohamad Jamal Zeidan. 2014. Corporate governance and market performance of parent firms following equity carve-out announcements. Journal of Management \& Governance 18: 471-503.

Chen, Kevin D., and Wayne R. Guay. 2020. Busy directors and shareholder satisfaction. Journal of Financial and Quantitative Analysis 55: 2181-210. [CrossRef]

Coles, Jeffrey L., and Chun-Keung Hoi. 2003. New evidence on the market for directors: Board membership and Pennsylvania Senate Bill 1310. Journal of Finance 58: 197-230. [CrossRef]

Coles, Jeffrey L., and Konari Uchida. 2018. Power of tournament incentives: Evidence from Japanese corporate boards. SSRN Working Paper. Available online: https:/ / papers.ssrn.com/sol3/papers.cfm?abstract_id=3100444 (accessed on 11 January 2018). [CrossRef]

Coles, Jeffrey L., Naveen D. Daniel, and Lalitha Naveen. 2008. Boards: Does one size fit all? Journal of Financial Economics 87: 329-56. [CrossRef]

Coles, Jeffrey L., Naveen D. Daniel, and Lalitha Naveen. 2014. Co-opted boards. Co-opted boards. Review of Financial Studies 27: 1751-96. [CrossRef]

Core, John E., Robert W. Holthausen, and David F. Larcker. 1999. Corporate governance, chief executive officer compensation, and firm performance. Journal of Financial Economics 51: 371-406. [CrossRef]

Daley, Lane, Vikas Mehrotra, and Ranjini Sivakumar. 1997. Corporate focus and value creation evidence from spinoffs. Journal of Financial Economics 45: 257-81. [CrossRef]

Dasilas, Apostolos, and Stergios Leventis. 2018. The performance of European equity carve-outs. Journal of Financial Stability 34 : 121-35. [CrossRef]

Desai, Chintal A., Mark S. Klock, and Sattar A. Mansi. 2011. On the acquisition of equity carve-outs. Journal of Banking $\mathcal{E}$ Finance 35: 3432-449.

Fama, Eugene F. 1980. Agency problems and the theory of the firm. Journal of Political Economy 88: 288-307. [CrossRef]

Fama, Eugene F., and Kenneth R. French. 2015. A five-factor asset pricing model. Journal of Financial Economics 116: 1-22. [CrossRef]

Feldman, Emilie R. 2016. Dual directors and the governance of corporate spinoffs. Academy of Management Journal 59: 1754-76. [CrossRef]

Fich, Eliezer M., and Anil Shivdasani. 2005. Are Busy Boards Effective Monitors? Journal of Finance 61: 689-724. [CrossRef]

Field, Laura, Michelle Lowry, and Anahit Mkrtchyan. 2013. Are busy boards detrimental? Journal of Financial Economics 109: 63-82. [CrossRef]

Fuchs, Daniel. 2003. The Motivation Behind the Carve-Out Decision-Evidence from German Equity Carve-Outs, EFMA Basel Meetings Paper. Available online: https:/ / papers.ssrn.com/sol3/papers.cfm?abstract_id=493702 (accessed on 1 August 2003).

Gilson, Stuart C. 1989. Management turnover and financial distress. Journal of Financial Economics 25: 241-62. [CrossRef]

Gilson, Stuart C. 1990. Bankruptcy, boards, banks, and blockholders: Evidence on changes in corporate ownership and control when firms default. Journal of Financial Economics 27: 355-87. [CrossRef]

Gulati, Ranjay, and Maxim Sytch. 2007. Dependence asymmetry and joint dependence in interorganizational relationships: Effects of embeddedness on a manufacturer's performance in procurement relationships. Administrative Science Quarterly 52: 32-69. [CrossRef]

Hermalin, Benjamin E., and Michael S. Weisbach. 1988. The determinants of board composition. Rand Journal of Economics 19: 589-606. [CrossRef]

Holmstrom, Bengt, and Joan Ricart I. Costa. 1986. Managerial incentives and capital management. Quarterly Journal of Economics 101: 835-60. [CrossRef]

Hulburt, Heather M., James A. Miles, and J. Randall Woolridge. 2002. Value creation from equity carve-outs. Financial Management 31: 83-100. [CrossRef] 
Ito, Kiyohiko. 1995. Japanese spinoffs: Unexplored survival strategies. Strategic Management Journal 16: 431-46. [CrossRef]

Ito, Kiyohiko, and Elizabeth L. Rose. 1994. The genealogical structure of Japanese firms: Parent-subsidiary relationships. Strategic Management Journal 15: 35-51. [CrossRef]

Klein, April, James Rosenfeld, and William Beranek. 1991. The two stages of an equity carve-out and the price response of parent and subsidiary stock. Managerial and Decision Economics 12: 449-60. [CrossRef]

Li, Xiaoyang, Angie Low, and Anil K. Makhija. 2017. Career concerns and the busy life of the young CEO. Journal of Corporate Finance 47: 88-109. [CrossRef]

Michaely, Roni, and Wayne H. Shaw. 1995. The choice of going public: Spin-offs vs. carve-outs. Financial Management 24: 5-21. [CrossRef]

Miwa, Yoshiro, and J. Mark Ramseyer. 2005. Who appoints them, what do they do? Evidence on outside directors from Japan. Journal of Economics \& Management Strategy 14: 299-337.

Moschieri, Caterina, and Johanna Mair. 2011. Adapting for innovation: Including divestitures in the debate. Long Range Planning 44: 4-25. [CrossRef]

Nanda, Vikram. 1991. On the good news in equity carve-outs. Journal of Finance 46: 1717-37. [CrossRef]

Narayanan, M. 1985. Managerial incentives for short-term results. Journal of Finance 40: 1469-84. [CrossRef]

Otsubo, Minoru. 2009. Gains from equity carve-outs and subsequent events. Journal of Business Research 62: 1207-13. [CrossRef]

Otsubo, Minoru. 2013. Value creation from financing in equity carve-outs: Evidence from Japan. Journal of Economics and Business 68: 52-69. [CrossRef]

Perotti, Enrico, and Silvia Rossetto. 2007. Unlocking value: Equity carve outs as strategic real options. Journal of Corporate Finance 13: 771-92. [CrossRef]

Powers, Eric A. 2003. Deciphering the motives for equity carve-outs. Journal of Financial Research 26: 31-50. [CrossRef]

Schipper, Katherine, and Abbie Smith. 1986. A comparison of equity carve-outs and seasoned equity offerings: Share price effects and corporate restructuring. Journal of Financial Economics 15: 153-86. [CrossRef]

Seward, James K., and James P. Walsh. 1996. The governance and control of voluntary corporate spin-offs. Strategic Management Journal 17: 25-39. [CrossRef]

Slovin, Myron B., Marie E. Sushka, and Steven R. Ferraro. 1995. A comparison of the information conveyed by equity carve-outs, spin-offs, and asset sell-offs. Journal of Financial Economics 37: 89-104. [CrossRef]

Wruck, Eric G., and Karen H. Wruck. 2002. Restructuring top management: Evidence from corporate spinoffs. Journal of Labor Economics 20: S176-S218. [CrossRef]

Xie, Jun. 2015. CEO career concerns and investment efficiency: Evidence from China. Emerging Markets Review 24: 149-59. [CrossRef]

Yim, Soojin. 2013. The acquisitiveness of youth: CEO age and acquisition behavior. Journal of Financial Economics 108: 250-73. [CrossRef]

Zhang, Teng, Sanjiv Sabherwal, Narayanan Jayaraman, and Stephen P. Ferris. 2016. The young and the restless: A study of age and acquisition propensity of CEOs of UK firms. Journal of Business Finance E Accounting 43: 1385-419. 